Branko Krnić*

Ivona Beljan **
JEL Classification C19, E32, G21, G39

Pregledni članak

https://doi.org/10.32910/ep.70.6.4

\title{
DINAMIKA PROMJENA FINANCIJSKOG POLOŽAJA I FINANCIJSKIH REZULTATA PODUZEĆA I BANAKA U HRVATSKOJ
}

Cilj ovog istraživanja je proširiti dosadašnje spoznaje o međuovisnosti funkcioniranja financijskog i realnog sektora u hrvatskoj ekonomiji. $U$ tu se svrhu istražuje dinamika promjena financijskog položaja i financijskih rezultata njihovih ključnih sastavnica, tj. poduzeća i banaka. U usporedbi s ranijim istraživanjima prošireni su aspekti analiziranja $i$ vremenski horizont analize, detaljnije se razmatra recesijsko razdoblje hrvatskog gospodarstva, a redefiniran je i obuhvat financijskih pokazatelja. Usporedbe se provode na temelju omjera, indeksa rasta i odnosa osnovnih stavki u okviru linearnih regresijskih modela te odabranih sektorskih financijskih pokazatelja. Utvrđene su razlike u kretanju dijela kategorija uspješnosti i financijskog položaja poduzeća i banaka u recesijskom razdoblju $i$ prikazano kako se pogoršava kvaliteta plasmana i s određenim pomakom profitabilnost banaka u uvjetima pogoršanja pokazatelja likvidnosti i solventnosti poduzeća. Nalazi istraživanja mogu pridonijeti boljem razumijevanju međuovisnosti kretanja financijske i realne sfere ekonomije te spoznavanju potrebe da se, uz makroekonomske indikatore, za pravovremeno prepoznavanje i otklanjanje me-

${ }^{*}$ Dr. sc. Branko Krnić, predstojnik Katedre za financije, računovodstvo i pravo, Veleučilište VERN', Zagreb (branko.krnic@vern.hr).

${ }^{* *}$ Ivona Beljan, struč. spec. oec., glavni analitičar, Riznica, Privredna banka Zagreb d. d., Zagreb (ivona.beljan@pbz.hr).

Rad je proizišao iz procesa izrade specijalističkog diplomskog stručnog rada Beljan (2017) za koji je mentor bio Branko Krnić.

Rad je primljen u uredništvo 20.04.2018. godine, a prihvaćen je za objavu 02.10.2018. godine. 
đusektorskih nesrazmjera, trebaju više koristiti komparativna sektorska analiza agregiranih podataka i pokazatelja iz financijskih izvještaja.

Ključne riječi: financijski položaj, uspješnost poslovanja, poduzeća, banke

\section{Uvod}

Teorijska i empirijska istraživanja pokazuju da neusklađenosti financijskog i realnog sektora često rezultiraju pogoršanjem ekonomskih performansi nacionalnih ekonomija. Za praćenje, prepoznavanje, pa i predviđanje pogoršanja po toj osnovi, u suvremenim uvjetima često ni široki obuhvat makroekonomskih indikatora više nije dovoljan. Pokazuje se nužnim dopuniti takve indikatore dodatnim pokazateljima dobivenim na temelju podataka iz financijskih izvještaja poslovnih subjekata na razini ključnih sektora. Identificiranje razlika u dinamici promjena financijskog položaja i financijskih rezultata ključnih sastavnica realnog i financijskog sektora, tj. poduzeća i banaka, može biti jedan od načina dobivanja dodatnih uvida u te svrhe. Polazeći od toga, odabran je i predmet ovog istraživanja. Rad je, dakle, usmjeren na istraživanje dinamike promjena osnovnih bilančnih stavki i stavki računa dobiti i gubitka poduzeća i banaka u Hrvatskoj u višegodišnjem razdoblju. Cilj je proširiti dosadašnje spoznaje o međuovisnosti funkcioniranja financijske i realne sfere nacionalne ekonomije na temelju analize financijskih performansi sektora poduzeća i bankovnog sektora.

U svrhu ostvarivanja definiranog cilja postavljaju se sljedeća istraživačka pitanja:

1. Pokazuju li omjeri i indeksi rasta odabranih stavki uspješnosti i financijskog položaja razlike u dinamici promjena između poduzeća i banaka? Polazeći od interakcija u poslovnim odnosima između poduzeća i banaka, koje se odražavaju u njihovim stavkama uspješnosti i bilančnim stavkama, analizom dinamike njihovih promjena iz godine u godinu moguće je utvrditi postoje li između njih znatnije razlike koje mogu generirati neusklađeno funkcioniranje financijskog i realnog sektora s posljedicama na makroekonomsku stabilnost.

2. Kakvi se odnosi između osnovnih stavki iskazuju u okviru linearnih regresijskih modela? Analizom dinamike promjena stavki uspješnosti i financijskog položaja, koja se provodi radi dobivanja odgovora na 1. istraživačko pitanje, dobiva se detaljan uvid u kretanja iz godine u godinu u promatranom razdoblju. Analiza koja se provodi radi dobivanja odgovora na 2. istraživačko pitanje, međutim, treba s aspekta koncepta povezanosti pokazati kakav je odnos između razmatranih varijabli poduzeća i banaka promatrano dugoročno, na temelju podataka za cijelo promatrano razdoblje. Nalazi u vezi s 2. pitanjem trebaju se razmatrati u kontekstu dobivenog 
odgovora na 1. pitanje, tj. utvrđenu povezanost na razini cijelog promatranog višegodišnjeg razdoblja treba razmatrati i s aspekta mogućih razlika u kretanju analiziranih varijabli iz godine u godinu. Na taj način npr. ocjena o jakoj povezanosti kretanja nekih od varijabli poduzeća i banaka na razini cijelog promatranog razdoblja još uvijek ne znači da u pojedinim godinama nije ostvarena i znatnija razlika u njihovom kretanju. Dakle, koncept povezanosti pokazat će odnos varijabli na dugoročnoj osnovi, a analiza dinamike je li i kada je ostvareno određeno odstupanje od usklađenog kretanja. S tog aspekta oba pitanja su relevantna za utvrđivanje usklađenosti financijske i realne sfere koja je predmet istraživanja u ovom radu.

3. Kakve su promjene kvalitete plasmana banaka u uvjetima pogoršanja likvidnosti, zaduženosti i solventnosti poduzeća? Analiza koja se provodi radi dobivanja odgovora na to pitanje trebala bi pružiti empirijski dokaz za teorijsku tezu da slabe financijske performanse realnog sektora utječu na pogoršanje financijskih performansi financijskog sektora. S obzirom da na pogoršanje financijskih performansi banaka mogu utjecati i druge sastavnice realnog sektora osim poduzeća, a da su te sastavnice izvan obuhvata ovog istraživanja, utjecaje slabih financijskih performansi poduzeća na banke razmatra se samo s aspekta pogoršanja kvalitete plasmana banaka.

4. Kako se ostvaruje profitabilnost banaka u uvjetima kontrakcije gospodarskih aktivnosti i pogoršanja financijskih performansi poduzeća? Ovo pitanje je također relevantno s aspekta potvrđivanja teorijske teze da slabe financijske performanse realnog sektora utječu na pogoršanje financijskih performansi financijskog sektora. Vrijede i u vezi s tim ograničenja koja su navedena uz 3. pitanje, tj. da na financijske performanse banaka mogu utjecati i druge sastavnice realnog sektora koje nisu u obuhvatu ovog istraživanja.

Uz ostvarenje cilja istraživanja, ovim se radom nastoji također pokazati kako podaci iz temeljnih financijskih izvještaja poslovnih subjekata, iskazani kao financijski pokazatelji na razini sektora poduzeća i bankovnog sektora, mogu biti značajna dopuna makroekonomskim indikatorima u spoznavanju stvarnog stanja nacionalne ekonomije. Naime, uobičajeno je teorijsko i normativno određenje, ali i iskustvo tzv. dobre prakse, da su podaci temeljnih financijskih izvještaja poslovnih subjekata od osobite važnosti za razne korisnike na mikro razini, kao npr. za menadžment, zaposlene, vlasnike, investitore i kreditore. Međutim, njihova važnost na makro razini nedovoljno se ističe. Nalazi komparativne analize financijskih pokazatelja sektora poduzeća i bankovnog sektora mogu nositeljima ekonomskih politika biti važna objašnjavajuća dopuna indikatora makroekonomskih kretanja.

Rad je strukturiran tako da je nakon prvog poglavlja, tj. uvoda iznesen teorijski okvir, a u trećem poglavlju prikazana metodologija istraživanja. Rezultati istraživanja izneseni su u četvrtom poglavlju, a na kraju rada, tj. u petom poglavlju iznesen je zaključak. 


\section{Teorijski okvir}

Povezanost funkcioniranja realne i financijske sfere ekonomije već je dugo predmet ekonomskih istraživanja (o tome vidjeti preglede literature u: Gertler, 1988; Pagano, 1993; Levine, 1997, 2004 i Demirgüç-Kunt i Levine, 2008, a o teorijskoj tezi o inherentnoj nestabilnosti financijskih sustava u Minsky, 1992 i 2008). U njima su primjenjivani različiti pristupi i korištene brojne mikroekonomske i makroekonomske varijable. Međutim, realni i financijski sektor uglavnom su razmatrani u odvojenim istraživanjima, a ne u usporednoj analizi. To se osobito odnosi na istraživanje njihovih ključnih sastavnica, tj. poduzeća i banaka.

U tako odvojenim financijskim analizama primjenjivani su različiti obuhvati financijskih pokazatelja (povijesni prikaz primjene financijskih pokazatelja može se vidjeti u Horrigen, 1968). To je omogućavalo uvide u financijski položaj i uspješnost poslovanja, kao i usporedbe u različitim kontekstima, te predviđanje budućih financijskih performansi. Tako su npr. u svrhu predviđanja bankrota poduzeća nakon rada Altman (1968) uslijedila brojna slična istraživanja. Znatan broj radova (nakon Stevens, 1973) odnosi se na istraživanje financijskih obilježja poduzeća koja su bila cilj korporacijskog preuzimanja. U nizu se studija uspoređuju financijska obilježja poduzeća pojedinih nacionalnih ekonomija po različitim osnovama (osobito nakon rada Kester, 1986). Dio takvih radova odnosi se i na istraživanja financijskih obilježja poduzeća čije dionice kotiraju na burzi. Pokazatelji financijskih performansi koriste se i u teorijskim i empirijskim istraživanjima rasta poduzeća (vidjeti pregled u Coad, 2009).

Isto su tako brojna istraživanja i financijskih performansi banaka. U njima se primjenom različitih ekonometrijskih tehnika za procjenu performansi kao varijable koriste različiti financijski pokazatelji (vidjeti npr. Berger i Humphrey, 1997; Berger i Mester, 1997; Demirguc-Kunt i Detragiache, 1998; Seiford i Zhu, 1999; Fries i Taci, 2004; Demirguc-Kunt, Detragiache i Gupta, 2006; Webb, 2010).

Financijski su pokazatelji u različitim obuhvatima obrađeni u više radova u domaćoj literaturi (vidjeti npr. Žager, 2001, Belak, 2014 i Žager, Mamić Sačer, Sever Mališ, Ježovita i Žager, 2017). U obradi teme ovog rada, kao polazište, relevantna su istraživanja koja su se temeljila na primjeni različitih financijskih pokazatelja za sektor poduzeća ili za bankovni sektor u Hrvatskoj. Tako se npr. u Belak i Aljinović (2008) indeksom poslovne izvrsnosti i pokazateljima uspješnosti istražuje izvrsnost poduzeća na tržištu kapitala u Hrvatskoj za višegodišnje razdoblje. U Ježovita i Žager (2014) se pomoću odabranih financijskih pokazatelja analizira zaduženost poduzeća, a u Ježovita (2015) sigurnost poslovanja poduzeća realnog sektora u Hrvatskoj. Bajo i Primorac (2016) na temelju podataka za razdoblje od 2009. do 2013. istražuju osnovna obilježja državnih poduzeća u Hrvatskoj (njihovo financijsko stanje, ključni trendovi u poslovanju, te razvojne perspektive). U istraživanju financijskih performansi banaka u domaćoj literaturi postoji također više 
radova. Tako npr. u Šverko, Pavlović i Vukas (2012) analizira se poslovanje malih banaka u Hrvatskoj. Pejić Bach, Posedel, i Stojanović (2009) i Kundid Škrabić i Ercegovac (2011). istražuju determinante profitabilnosti banaka u Hrvatskoj.

Financijski se pokazatelji koriste u ekonomskoj literaturi u brojnim autorskim istraživanjima, kao i istraživanjima u okviru međunarodnih institucija. Međunarodni monetarni fond, Europska komisija i Eurostat, Svjetska banka, ali i središnje banke brojnih zemalja razvili su različite sustave pokazatelja. Središnje banke primjenjuju širok spektar pokazatelja u istraživanjima financijske stabilnosti (pa tako i Hrvatska narodna banka u posebnoj publikaciji na tom području). Pregled istraživanja usmjerenih na područje financijske stabilnosti može se vidjeti u Gadanecz i Jayaram (2009) i u domaćoj literaturi u Dumičić (2015).

Za makroekonomsku stabilnost jedan od ključnih preduvjeta je i usklađeno funkcioniranje financijskog i realnog sektora. $\mathrm{S}$ tog aspekta mogu se pojavljivati različite deformacije i neravnoteže. Njihovo pravovremeno identificiranje i otklanjanje preduvjet je uspješnog funkcioniranja nacionalne ekonomije. U tu svrhu uobičajeno je praćenje različitih indikatora makroekonomske i financijske stabilnosti. Međutim, tome bi mogla bitno pridonijeti i financijska analiza ključnih sastavnica realnog i financijskog sektora, tj. poduzeća i banaka. Na temelju analize dinamike promjena aktivnih i pasivnih bilančnih stavki poduzeća i banaka te stavki uspješnosti moguće je identificirati kretanja koja mogu uzrokovati nestabilnost nacionalne ekonomije. Međutim, još su općenito rijetki radovi u kojima se na temelju pokazatelja iz temeljnih financijskih izvještaja provodi usporedna analiza financijskih performansi sektora poduzeća i bankovnog sektora. Takvi bi radovi mogli znatno pridonijeti cjelovitijim uvidima u njihovu međuovisnost i ojačati spoznaju o potrebi korištenja rezultata komparativne financijske analize sektora poduzeća i bankovnog sektora kao dopune makroekonomskim analizama i prognozama. Naime, između stavki bankovne bilančne aktive i bilančne pasive poduzeća postoji široki obuhvat različitih povezanosti. Tako npr. stavke u bilančnoj aktivi banaka, koje za banke predstavljaju različite plasmane poduzećima, u bilančnoj pasivi poduzeća predstavljaju njihove izvore financiranja. To omogućuje analiziranje pozicija banaka i poduzeća s različitih aspekata. Isto tako interakcija funkcionira i preko stavki računa dobiti i gubitka poduzeća i banaka. Tako npr. kamatni prihodi, prihodi od provizija i naknada koje banke zaračunavaju u poslovnim odnosima s poduzećima i po osnovi kojih ostvaruju novčane priljeve, predstavljaju stavke rashoda u računu dobiti i gubitka poduzeća te novčane odljeve u njihovim novčanim tijekovima. To znači da je financijske performanse poduzeća i banaka moguće razmatrati u kontekstu njihovih interakcija i na tim osnovama identificirati kretanja koja bi mogla uzrokovati neravnoteže s posljedicama na makroekonomsku stabilnost (o tome i u Krnić, 2017, str. 104). Imajući to u vidu, ovaj se rad nastavlja na istraživanje neusklađenosti financijskog i realnog sektora i njihove povezanosti s makroekonomskim neravnotežama u hrvatskoj ekonomiji provedenim u Krnić i Radošević 
(2014). Nadalje, kao polazište, uzima se u obzir i istraživanje rizika financijske stabilnosti u Krnić (2016) na temelju širokog obuhvata makroekonomskih i mikroekonomskih pokazatelja i u okviru toga i odabranih financijskih pokazatelja za poduzeća i banke za 2014. i 2015. godinu. Financijske performanse poduzeća i banaka u Hrvatskoj za razdoblje od 2001. do 2015. godine, s više različitih aspekata istraživane su i u Krnić (2017). Sva navedena istraživanja ukazala su na potrebu njihovog produbljivanja dodatnim aspektima analiziranja na redefiniranom obuhvatu pokazatelja, uz proširenje vremenskog horizonta analize. Imajući to u vidu u ovo istraživanje uključeni su podaci za 2016. godinu i recesijsko se razdoblje hrvatskog gospodarstva analizira detaljnije s aspekta dinamike promjena osnovnih bilančnih i stavki uspješnosti. Uz stavljanje dobivenih nalaza u širi ekonomski i društveni kontekst u budućim istraživanjima, to može još više pridonijeti boljem razumijevanju međuovisnosti funkcioniranja realne i financijske sfere nacionalne ekonomije, kao i potrebe da se, uz makroekonomske indikatore, za pravovremeno prepoznavanje i otklanjanje međusektorskih nesrazmjera, više koriste i pokazatelji na temelju sektorskih podataka iz financijskih izvještaja poduzeća i banaka. Na tim osnovama nastoji se realizirati i istraživanje u okviru ovog rada. Pri tome se, uz ostvarenje eksplicitnog cilja istraživanja, nastoji ukazati da pokazatelji iz financijskih izvještaja poslovnih subjekata nisu samo od osobite važnosti za do sada najčešće proklamirane namjene zainteresiranih unutarnjih i vanjskih korisnika, nego i na makro razini za nositelje ekonomske politike.

\section{Podaci i metodologija istraživanja}

Istraživanje se temelji na podacima financijskih izvještaja poslovnih subjekata za razdoblje od 2001. do 2016. godine iskazanih na razini sektora poduzeća i bankovnog sektora u Hrvatskoj. Slijedi objavljivanje Hrvatske narodne banke prema kojem domaće sektore sačinjavaju: sektor poduzeća, financijski sektor (u okviru kojeg su banke ključne institucije), opća država i stanovništvo. Pod poduzećem se u kontekstu objavljivanja Financijske agencije podrazumijevaju poduzetnici koji su obveznici poreza na dobit, bez uključivanja banaka, osiguravajućih društava i drugih financijskih institucija. S obzirom da nisu uključene banke i osiguravajuća društva pod sektorom poduzeća se u kontekstu ovog istraživanja razumijevaju tzv. nefinancijska poduzeća (kako se i klasificiraju u okviru monetarne statistike). Stoga kada se u radu i koristi termin sektor poduzeća sadržajno se radi o sektoru nefinancijskih poduzeća. Za poduzeća se koriste podaci koje objavljuje Financijska agencija na temelju zaprimljenih financijskih izvještaja poslovnih subjekata (Financijska agencija, Analiza financijskih rezultata poduzetnika Republike Hrvatske, razne godine). Za banke se koriste podaci koje objavlju- 
je Hrvatska narodna banka (Bilten, Bilten o bankama, Financijska stabilnost, Godišnje izvješće).

Stavke i pokazatelji financijskih performansi poduzeća i banaka koji su uključeni u istraživanje navedeni su u Okviru 1.

\section{Okvir 1 .}

\section{STAVKE I POKAZATELJI FNANCIJSKIH PERFORMANSI PODUZEĆA (P) I BANAKA B) - ZNAČENJE KRATICA}

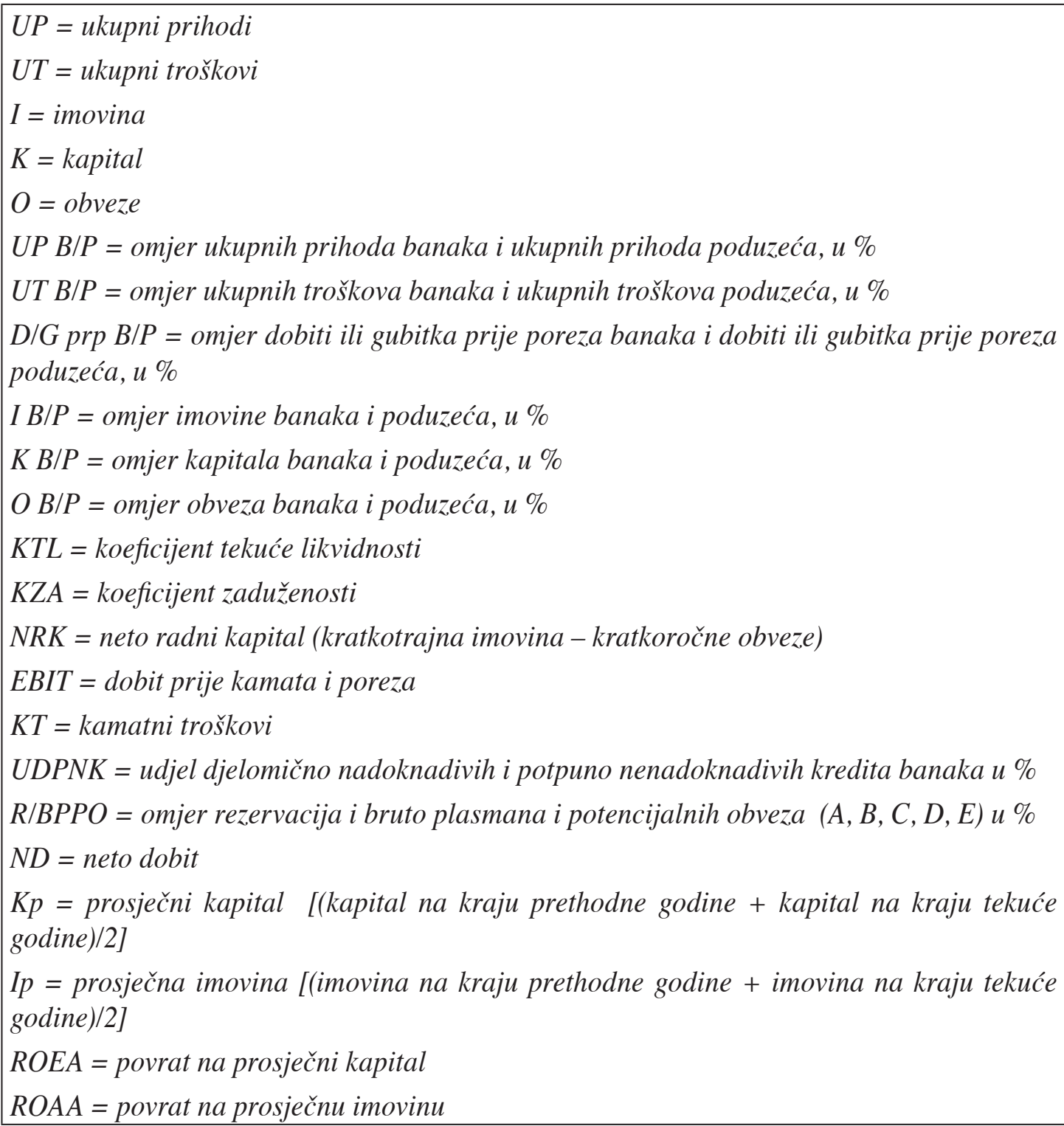

Izvor: Vlastiti prikaz autora. 
S obzirom da su odabrane stavke iz financijskih izvještaja i na temelju njih izračunani financijski pokazatelji iskazani na razini sektora nefinancijskih poduzeća, u interpretaciji rezultata treba imati u vidu da se razine ostvarenja pojedinih gospodarskih djelatnosti mogu i znatnije razlikovati. Stavke i pokazatelji koji se analiziraju u ovom radu omogućuju uvid u dinamiku promjena uspješnosti i financijskog položaja sektora nefinancijskih poduzeća promatrano u cjelini. Na taj način mogu na makro razini biti dopuna makroekonomskim pokazateljima u objektivizaciji stanja te predviđanju budućih kretanja, kao i podloga za osmišljavanje korekcija ekonomske politike.

Usporedbe se provode na temelju omjera, indeksa rasta i odnosa osnovnih stavki te odabranih sektorskih financijskih pokazatelja uspješnosti i financijskog položaja poduzeća i banaka (više o odabranim pokazateljima u npr. Belak, 2014 i Krnić, 2017). Odnosi između osnovnih stavki utvrđuju se u okviru linearnih regresijskih modela i interpretiraju na temelju output tablice regresijske analize, tj. uzimajući u obzir: koeficijent korelacije (Multiple $R$ ), koeficijent determinacije ( $R$ Square), prilagođeni koeficijent determinacije (Adjusted $R$ Square) i značajnost (Significance F).

Uz omjere navedene u Okviru 1. u radu se koristi i nekoliko standardnih financijskih pokazatelja (šire obuhvate vidjeti u Belak, 2014 i Krnić 2017), tj.: koeficijent tekuće likvidnosti, koeficijent zaduženosti, odnos neto radni kapital i imovina, odnos dobiti prije kamata i poreza i kamatnih troškova, te povrat na prosječni kapital i povrat na prosječnu imovinu.

Koeficijent tekuće likvidnosti - KTL (tekući odnos, tekući omjer - engl. Current Ratio) mjeri sposobnost podmirivanja kratkoročnih (tekućih) obveza kratkotrajnom (tekućom) imovinom. Koeficijent zaduženosti - KZA (Debt Ratio) pokazuje koliki je dio imovine financiran iz ukupnih obveza. Odnos neto radnog kapitala i ukupne imovine - NRK/I (Working Capital to Assets) mjeri postotni udio radnog kapitala u ukupnoj imovini. Razlikuje se dakle - bruto radni kapital (Gross Working Capital) i neto radni kapital (Net Working Capital). Bruto radni kapital je kratkotrajna (tekuća imovina), a neto radni kapital razlika između kratkotrajne (tekuće) imovine i kratkoročnih (tekućih) obveza. Pokriće kamata, tj. EBIT/KT (Times Interest Earned Ratio, Interest Coverage Ratio) pokazuje sposobnost pokrivanja troškova kamata tj. koliko su izraženo u postotku troškovi kamata pokriveni zaradom prije kamata i poreza izraženom EBIT-om (EBIT - Earnings Before Interest and Taxes). Pri tome se u radu termin troškovi koristi u značenju rashoda, iako se u računovodstvenoj teoriji, normativi i praksi ta dva pojma sadržajno razlikuju. Povrat na prosječni kapital - ROEA (Return on Average Capital) je postotni omjer neto dobiti i prosječnog kapitala. Povrat na prosječnu imovinu - ROAA (Return on Average Assets) je postotni omjer neto dobiti i prosječne imovine (O tome više u: Žager, 2001, Belak, 2014, Krnić, 2017, Žager, Mamić Sačer, Sever Mališ, Ježovita i Žager, 2017).

Obuhvat pokazatelja financijskih performansi poduzeća i banaka, njihova obrada i iskazivanje rezultata postavljeni su na način koji omogućuje dobivanje odgovora na istraživačka pitanja. 
B. KRNIĆ i I. BELJAN: Dinamika promjena financijskog položaja i financijskih rezultata poduzeća i banaka... EKONOMSKI PREGLED, 70 (6) 869-894 (2019)

\section{Rezultati istraživanja pokazatelja financijskih performansi poduzeća i banaka u Hrvatskoj}

\subsection{Usporedbe osnovnih stavki uspješnosti i financijskog položaja poduzeća i banaka u Hrvatskoj}

Usporedbe stavki uspješnosti i financijskog položaja poduzeća i banaka u Hrvatskoj provode se na temelju njihovih omjera (tablica 1.), indeksa njihovih promjena u odnosu na 2001. (grafički prikazi 1. i 2.) i njihovih odnosa u linearnom regresijskom modelu (grafički prikaz 3.). Pokazuje se također i kako nalazi istraživanja financijskih pokazatelja mogu biti objašnjavajuća dopuna indikatora makroekonomskih kretanja.

Tablica 1.

\section{OMJERI OSNOVNIH STAVKI RAČUNA DOBITI I GUBITKA I BILANČNIH STAVKI PODUZEĆA I BANAKA U HRVATSKOJ U RAZDOBLJU OD 2001. DO 2016. GODINE U \%}

\begin{tabular}{|c|c|c|r|r|r|r|}
\hline & $\mathrm{UP} \mathrm{B} / \mathrm{P}$ & $\mathrm{UT} \mathrm{B} / \mathrm{P}$ & $\mathrm{D} / \mathrm{G}$ prp B/P & $\mathrm{I} \mathrm{B/P}$ & $\mathrm{K} \mathrm{B} / \mathrm{P}$ & $\mathrm{O} \mathrm{B} / \mathrm{P}$ \\
\hline 2001. & 3,6 & 3,3 & 21,0 & 27,7 & 4,6 & 56,8 \\
\hline 2002. & 3,6 & 3,0 & 18,3 & 30,0 & 5,6 & 55,4 \\
\hline 2003. & 3,5 & 2,9 & 27,4 & 31,0 & 5,6 & 55,6 \\
\hline 2004. & 3,5 & 2,8 & 26,7 & 30,7 & 5,8 & 56,6 \\
\hline 2005. & 3,4 & 2,8 & 18,6 & 33,4 & 6,4 & 57,2 \\
\hline 2006. & 3,4 & 2,9 & 15,8 & 34,9 & 7,9 & 57,2 \\
\hline 2007. & 3,7 & 3,1 & 16,0 & 35,1 & 10,2 & 53,4 \\
\hline 2008. & 4,0 & 3,3 & 23,7 & 35,1 & 12,1 & 51,3 \\
\hline 2009. & 5,0 & 4,4 & 44,4 & 34,8 & 12,3 & 49,4 \\
\hline 2010. & 4,7 & 4,0 & 103,3 & 36,5 & 14,2 & 48,9 \\
\hline 2011. & 4,5 & 3,8 & 37,5 & 37,7 & 14,9 & 49,8 \\
\hline 2012. & 4,6 & 4,1 & 37,6 & 37,7 & 15,9 & 48,9 \\
\hline 2013. & 4,4 & 4,3 & 9,4 & 37,3 & 15,1 & 49,0 \\
\hline 2014. & 4,2 & 3,9 & 14,9 & 36,8 & 14,8 & 48,6 \\
\hline 2015. & 3,8 & 4,8 & $\ldots$ & 36,1 & 12,4 & 49,9 \\
\hline 2016. & 3,9 & 3,0 & 19,9 & 36,2 & 13,1 & 51,1 \\
\hline
\end{tabular}

Izvor: Izračun autora iz podataka preuzetih iz godišnjih publikacija: Financijska agencija, Analiza financijskih rezultata poduzetnika Republike Hrvatske i Hrvatska narodna banka: Godišnje izvješće $i$ Bilten o bankama. 
U promatranom razdoblju najviši je omjer ukupnih prihoda banaka i ukupnih prihoda poduzeća bio u 2009. godini. Godišnja povećanja ukupnih prihoda poduzeća ostvaruju se u cijelom predrecesijskom razdoblju, tj. od 2001. - 2008., a u 2008. je ostvarena i njihova najviša razina. Međutim, nakon znatnog smanjenja u 2009. godini, unatoč pozitivnim promjenama u pojedinim godinama, oporavak na razinu iz 2008. nije uslijedio do kraja promatranog razdoblja. Ukupni prihodi banaka su se povećavali sve do 2009., kada je ostvarena njihova najviša razina. Od tada se uglavnom smanjuju i u 2016. su znatno ispod ukupnih prihoda ostvarenih u 2009. godini. Pokazuje se da je do zaključno 2007. godine dinamika ostvarivanja ukupnih prihoda poduzeća i banaka bila u znatnoj mjeri usklađena. Međutim, od 2008. godine, odnosno u cijelom recesijskom razdoblju, indeksi rasta ukupnih prihoda u odnosu na 2001. godinu viši su u bankama nego u poduzećima.

U recesijskoj 2009. godini banke su ostvarile najvišu razinu ukupnih prihoda, a poduzeća istodobno najveće smanjenje. Uvid u podatke iz računa dobiti i gubitaka na razini bankovnog sektora pokazuje da su u 2009. godini banke ostvarile najvišu razinu kamatnih prihoda i ostalih nekamatnih prihoda te tako i ukupnih prihoda u cijelom promatranom razdoblju od 2001. do 2016. godine. Takvi nesrazmjeri u kretanjima osnovnih stavki u računu dobiti i gubitaka poduzeća i banaka trebali su na makro razini biti dokaz o dimenzijama nastupajuće kontrakcije gospodarskih aktivnosti (vidjeti grafički prikaz 1.) koji će s vremenskim pomakom imati i znatan negativan utjecaj na banke (što se vidi i u tada već započetom znatnom povećanju ispravaka vrijednosti po osnovi loših plasmana banaka). Makroekonomski indikatori za 2009. godinu potvrdili su izrazito veliku kontrakciju gospodarskih aktivnosti, tj. ostvaren je pad BDP-a (bruto domaćeg proizvoda) po realnoj godišnjoj stopi od 7,4\%, smanjen je izvoz roba i usluga, povećan inozemni dug i dug opće države i započelo je višegodišnje povećanje stope nezaposlenosti i smanjenje stope zaposlenosti (HNB, 2018).

Financijski izvještaji za nefinancijska poduzeća otkrili su u kojim djelatnostima je ostvaren najveći pad gospodarske aktivnosti i povezano s tim ukupnih prihoda. Kombinacija pokazatelja iz financijskih izvještaja poduzeća i banaka, izraženih na razini sektora nefinancijskih poduzeća i bankovnog sektora uz makroekonomske indikatore, mogli su biti dobra informacijska podloga za ocjenu stanja u realnom i financijskom sektoru hrvatske ekonomije i za sveobuhvatno redizajniranje ekonomske politike. Ostaje pitanje - u kolikoj mjeri je i s kakvim učincima takva informacijska podloga do sada korištena. Međutim, traženje odgovora na to, prema uvodno postavljenim ciljevima i istraživačkim pitanjima, prelazi zadane okvire ovog rada.

Najveći omjeri ukupnih troškova banaka i ukupnih troškova poduzeća ostvareni su u 2009. i 2015. godini (u kojoj su nastali povećani rashodi banaka po osnovi konverzije kredita u CHF). Iz grafičkog prikaza 1. vidljiva je manja usklađenost kretanja ukupnih troškova poduzeća i banaka u razdoblju prije recesije od ostvarivanja ukupnih prihoda. Indeksi rasta ukupnih troškova u odnosu na 2001. godinu 
do zaključno 2007. viši su za poduzeća. To se može povezati s rastom ukupnih prihoda poduzeća u razdoblju gospodarskog rasta. Od 2009. do 2015., tj. u najvećem dijelu recesijskog razdoblja viši su za banke.

Grafički prikaz, 1 .

\section{UKUPNI PRIHODI I UKUPNI RASHODI PODUZEĆA I BANAKA U HRVATSKOJ U RAZDOBLJU OD 2001. DO 2016. GODINE}

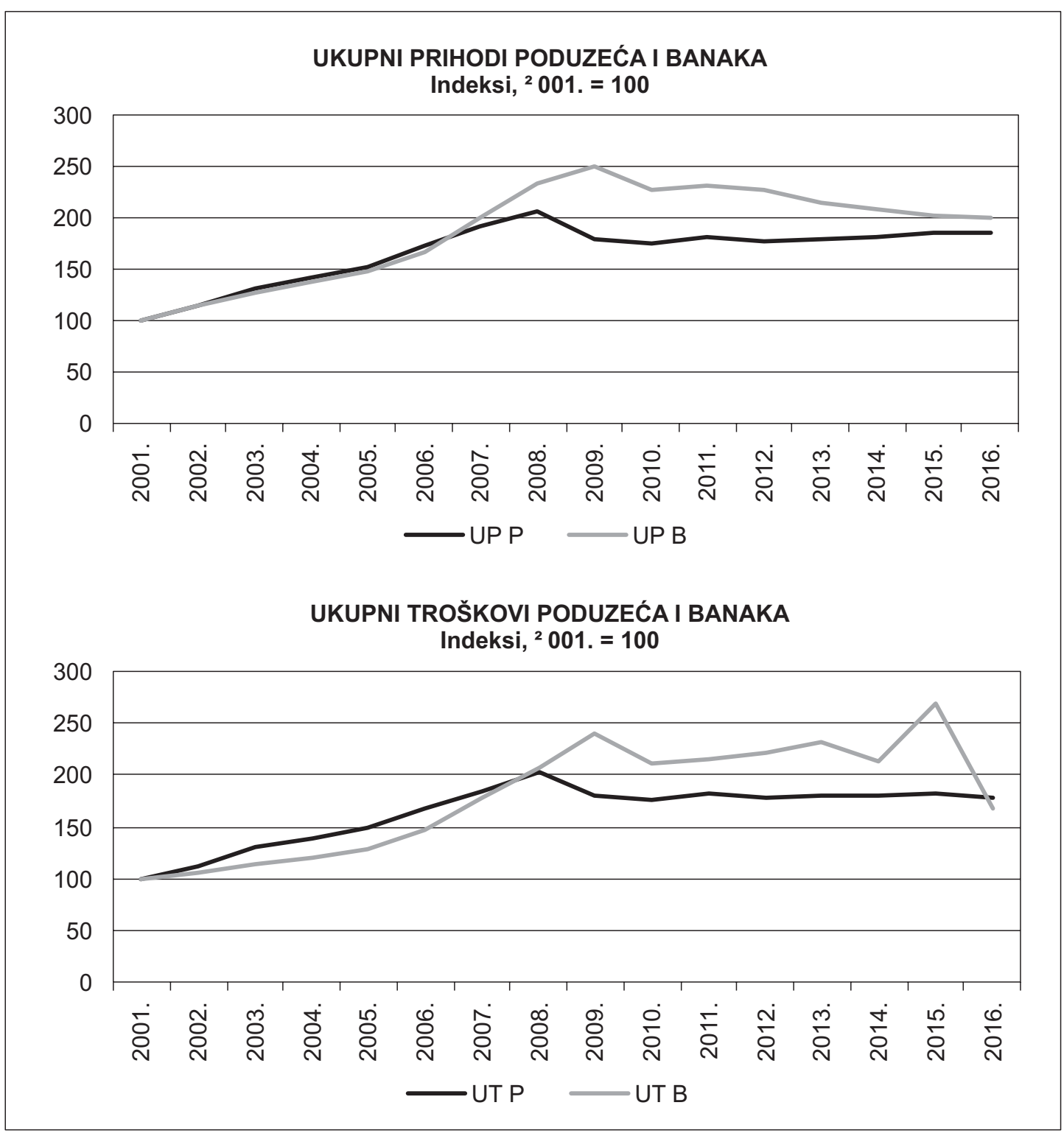

Izvor: Na temelju izračuna autora iz podataka preuzetih iz godišnjih publikacija: Financijska agencija, Analiza financijskih rezultata poduzetnika Republike Hrvatske i Hrvatska narodna banka: Godišnje izvješće i Bilten o bankama. 
U razmatranju kretanja imovine poslovnih subjekata u sektoru nefinancijskih poduzeća i bankovnom sektoru treba razlikovati mehanizme promjena njihovih bilančnih aktiva prema prirodi njihove djelatnosti i pozicije u ekonomskom sustavu. Bitna razlika proizlazi iz činjenice što su bilančne aktive banaka pod neposrednim utjecajem monetarne politike kojom se regulira multiplikacija depozita i kredita. Povezano s tim, krediti su i dominantna stavka u bilancama banaka pa njihove promjene u znatnom dijelu objašnjavaju i promjene njihove ukupne imovine.

Omjer imovine banaka i imovine poduzeća se od recesijske 2010. godine nadalje ostvarivao na višoj razini nego u razdoblju do 2009. godine. U cijelom recesijskom razdoblju u bankama se iskazuje znatno viši indeks porasta imovine u odnosu na 2001. godinu (vidjeti grafički prikaz 2.) u usporedbi s poduzećima. Naime, imovina poduzeća se do 2009. povećavala, a nakon toga, u razdoblju recesije, uslijedilo je smanjenje ili stagnacija. Imovina banaka se povećavala sve do 2011. godine i tek od tada se smanjuje. Bilance banaka iskazane na razini bankovnog sektora ukazuju na smanjenje ključne sastavnice njihove imovine, tj. kreditnih plasmana. Smanjivanje kreditnog portfelja banaka u razdoblju od 2012. do 2016. povezan je s intenzivnijom prodajom neprihodonosnih potraživanja, djelomičnim otpisa glavnice kredita zbog konverzije kredita uz švicarski franak, tečajnim kretanjima, ali i izlaskom dviju banaka iz sustava (HNB, 2017). Detaljnija analitika bilančnih stavki pruža uvid u strukturu i promjene kredita banaka prema sektorskoj podijeli (država, poduzeća, stanovništvo) i predstavlja također dobru analitičku podlogu za redizajniranja u regulaciji i ekonomskoj politici.

Omjer kapitala banaka i kapitala poduzeća od 2001. godine se povećavao i na kraju 2012. dosegnuta je njegova najviša razina. U kretanju kapitala poduzeća razlikuju se tri faze: povećanje do 2009., smanjenje do 2012., te postupni rast nakon toga. Kapital banaka se povećavao sve do 2012., a onda stagnirao do 2014. godine. U 2015. godini ostvareno je smanjenje koje se najvećim dijelom povezuje porastom rashoda i gubicima kao posljedicom konverzije kredita vezanih uz valutnu klauzulu u švicarskim francima. Kapital banaka znatnije se povećao u predrecesijskom razdoblju, tako da su u razdoblju recesije hrvatskog gospodarstva banke iskazivale više indekse rasta kapitala od poduzeća, u usporedbi s 2001. godinom (vidjeti grafički prikaz 2.).

Formirani kapital banaka u predrecesijskom razdoblju osiguravao je stabilnost bankovnog sustava u razdoblju recesije hrvatskog gospodarstva. Međutim, produljena recesija imala je povratni negativni utjecaj i na poslovanje banaka $u$ vidu smanjenja prihoda i povećanja rashoda po osnovi ispravaka vrijednosti, a to je rezultiralo stagniranjem te pri kraju promatranog razdoblja i smanjenjem kapitala. Analitičke podloge o promjenama u strukturi kapitala sektora nefinancijskih poduzeća i bankovnog sektora pružaju također mogućnost da se, uz makroekonomske indikatore, pravovremeno identificiraju sektorski nesrazmjeri i pronađu adekvatne regulacijske mjere za njihovo usklađeno funkcioniranje. 
B. KRNIĆ i I. BELJAN: Dinamika promjena financijskog položaja i financijskih rezultata poduzeća i banaka.. EKONOMSKI PREGLED, 70 (6) 869-894 (2019)

Grafički prikaz 2.

\section{IMOVINA, KAPITAL I OBVEZE PODUZEĆA I BANAKA U HRVATSKOJ U RAZDOBLJU OD 2001. DO 2016. GODINE}

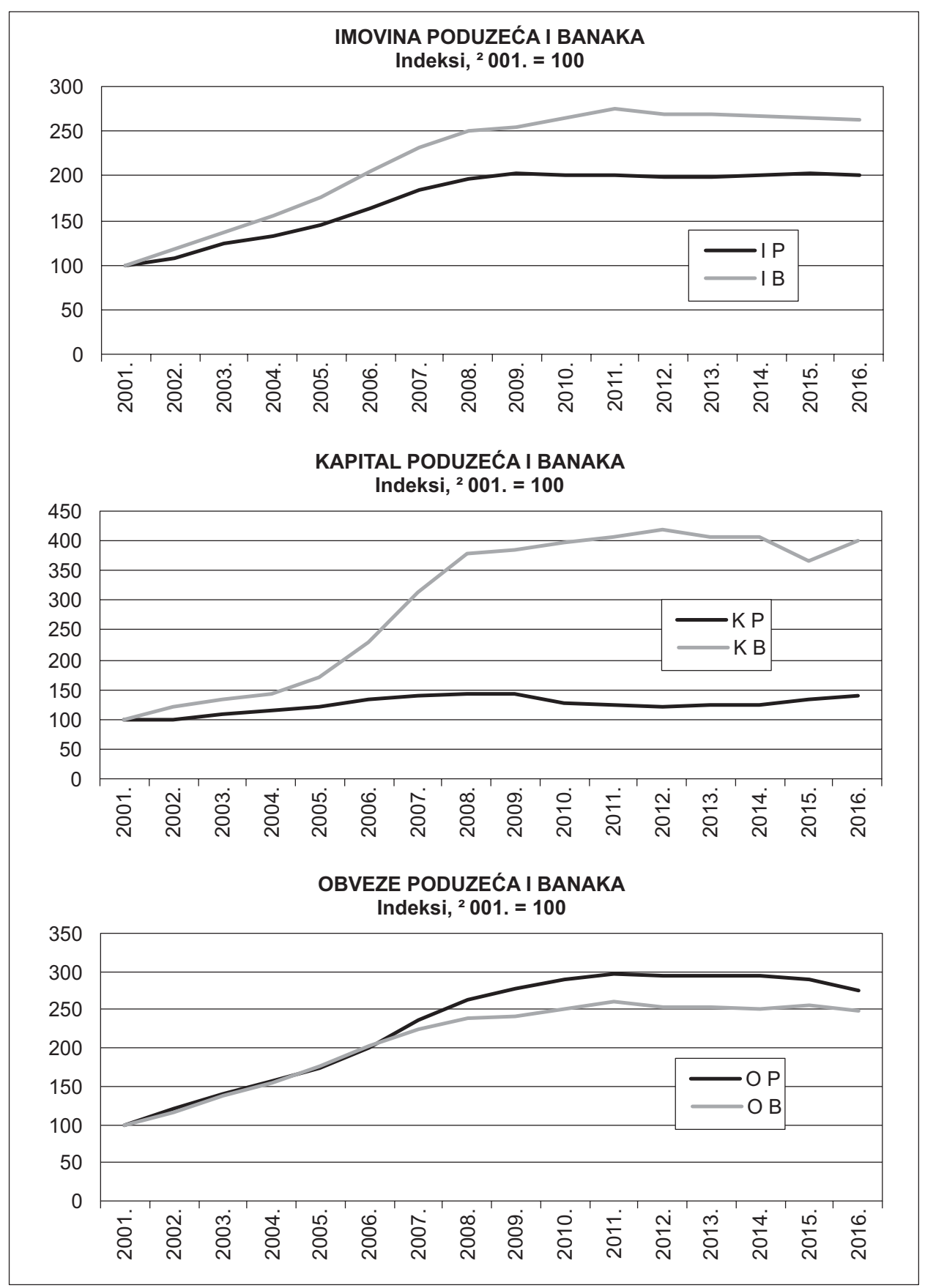

Izvor: Na temelju izračuna autora iz podataka preuzetih iz godišnjih publikacija: Financijska agencija, Analiza financijskih rezultata poduzetnika Republike Hrvatske i Hrvatska narodna banka: Godišnje izvješće i Bilten o bankama. 
Omjer obveza banaka i obveza poduzeća se nakon smanjenja u 2002. godini povećavao sve do 2006. godine. Od 2007. do 2010. godine taj se omjer smanjivao, a manje povećanje uslijedilo je u 2011. godini. Nakon toga izmjenjivale su se faze smanjenja i stagniranja do 2014. godine, te povećanja omjera do kraja promatranog razdoblja. Obveze poduzeća su se sve do 2011. godine povećavale. Njihovo zaduživanje podržavano je znatnom ponudom kredita inozemnih i domaćih banaka. Ino zaduživanje poduzeća izrazito se povećalo u 2007. godini. Rast ekonomskih aktivnosti izražen rastom ukupnih prihoda sve do 2008. godine stvarao je privid održivosti takvog njihovog zaduživanja. Unatoč tome što je smanjenje ukupnih prihoda poduzeća u 2009. bio indikator neodrživosti dostignute razine duga, zaduživanje je nastavljeno sve do 2011. godine. Tek nakon toga uslijedilo je postupno smanjenje njihovih obveza do 2016. godine. Indeksi rasta obveza poduzeća u odnosu na 2001. godinu u cijelom su recesijskom razdoblju na višoj razini od indeksa rasta obveza banaka (vidjeti grafički prikaz 2.).

Obveze banaka su se do zaključno 2011. također povećavale, a nakon toga uslijedilo je smanjenje i stagnacija na nižoj razini s većim smanjenjem u 2016. godini. Naime, potkraj promatranog razdoblja smanjivali su se dugoročni izvori financiranja banaka zbog usmjeravanja sektora poduzeća (ali i sektora stanovništva) na tekuću likvidnost. Kontrakcija u bilančnoj pasivi nastaje i zbog smanjenja inozemnih izvora tj. smanjenja ino-kredita i povlačenju depozita inozemnih banaka.

Istraživanje odnosa stavki uspješnosti poduzeća i banaka ukazuje na različite stupnjeve njihove povezanosti (grafički prikaz 3.). Iskazana je jaka pozitivna veza između dinamike promjena ukupnih prihoda poduzeća i ukupnih prihoda banaka (koeficijent korelacije 0,90). Potvrđena je i značajnost koeficijenta korelacije i reprezentativnost regresijskog modela. Za razliku od takve povezanosti ukupnih prihoda, povezanost ukupnih rashoda poduzeća i ukupnih rashoda banaka utvrđena je na nižoj razini. Međutim, dobiveni koeficijent korelacije $(0,83)$ također je $u$ okviru raspona koji odražava jaku pozitivnu vezu. Koeficijenti determinacije (nekorigirani 0,69 i korigirani 0,67) su manji od takvih koeficijenta u proceduri ispitivanja povezanosti ukupnih prihoda poduzeća i ukupnih prihoda banaka. Dakle, iako su povezanosti razmatranih varijabli uspješnosti za sektor nefinancijskih poduzeća i bankovni sektor u okviru regresijske procedure za cijelo promatrano razdoblje od 2001. do 2016. godine na razini jake pozitivne veze, raspon do potpune povezanosti ipak je toliki da u pojedinim kraćim razdobljima ostvaruju razlike u njihovoj dinamici i razini promjena. To nedvojbeno potvrđuju i opisane razlike za razmatrano recesijsko razdoblje.

Istraživanje odnosa stavki financijskog položaja poduzeća i banaka također ukazuje na različite stupnjeve povezanosti njihovog kretanja (grafički prikaz 3.). Korelacijski koeficijent $(0,99)$ odražava jaku povezanost dinamike promjena imovine poduzeća i imovine banaka. $U$ vezi s tim iskazani su i visoki koeficijenti 
B. KRNIĆ i I. BELJAN: Dinamika promjena financijskog položaja i financijskih rezultata poduzeća i banaka...

EKONOMSKI PREGLED, 70 (6) 869-894 (2019)

Grafički prikaz 3.

\section{LINEARNI REGRESIJSKI MODELI ZA STAVKE USPJEŠNOSTI I BILANČNE STAVKE PODUZEĆA I BANAKA U HRVATSKOJ U RAZDOBLJU OD 2001. DO 2016. GODINE}

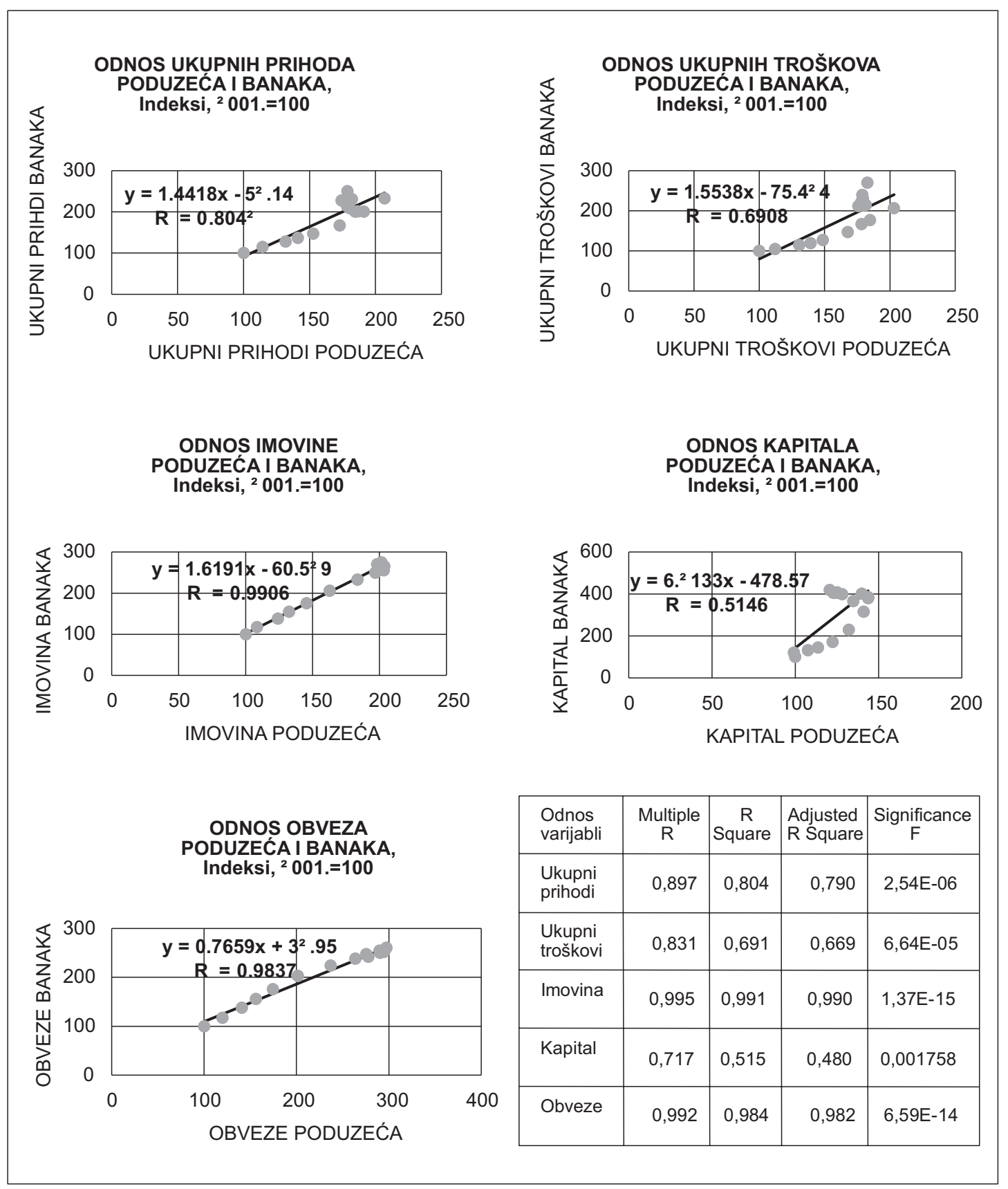

Izvor: Na temelju izračuna autora iz podataka preuzetih iz godišnjih publikacija: Financijska agencija, Analiza financijskih rezultata poduzetnika Republike Hrvatske i Hrvatska narodna banka: Godišnje izvješće i Bilten o bankama. 
determinacije (nekorigirani 0,99 i korigirani 0,98) i potvrđena značajnost dobivenog koeficijenta korelacije. U istraživanju odnosa stavki kapitala nalazi su bitno drukčiji. Naime, povezanost dinamike promjena kapitala poduzeća i kapitala banaka utvrđena je na razini srednje jake pozitivne veze (koeficijent korelacije 0,71) s potvrđenom značajnošću. Relativno niski koeficijenti determinacije (nekorigirani 0,51 i korigirani 0,48 ) odražavaju povezanost koja se klasificira između slabe i srednje jakosti. Nadalje, korelacijski koeficijent $(0,99)$ pokazuje i jaku povezanost dinamike promjena obveza poduzeća i obveza banaka. Ta je povezanost potvrđena i visokim koeficijentima determinacije (nekorigirani 0,98 i korigirani 0,98). U output tablici regresijske analize potvrđena je i značajnost dobivenog koeficijenta korelacije.

Utvrđene povezanosti razmatranih varijabli financijskog položaja za sektor nefinancijskih poduzeća i bankovni sektor u okviru regresijske procedure za cijelo promatrano razdoblje od 2001. do 2016. godine ukazuju da se osobito na stavkama kapitala u pojedinim kraćim razdobljima mogu ostvarivati razlike u njihovoj dinamici i razini promjena. Takva kretanja su i potvrđena identificiranim razlikama za razmatrano recesijsko razdoblje.

\subsection{Likvidnost, zaduženost $i$ solventnost poduzeća i kvaliteta plasmana banaka}

Za razmatranje promjena u kvaliteti plasmana banaka bitno je istražiti financijske performanse poduzeća koje se odnose na likvidnost, zaduženost i solventnost poduzeća. Kretanje likvidnosti, zaduženosti i solventnosti poduzeća, te kvaliteta plasmana banaka u promatranom razdoblju vidljiva je iz grafičkog prikaza 4.

Od 2001. do zaključno 2007. godine, tekuća likvidnost poduzeća se kontinuirano povećavala. Koeficijent je na najvišoj razini bio 2007. godine. Od 2008. do 2013. godine, s iznimkom 2011., tekuća likvidnost se smanjivala (u 2013. je na razini 1,01). Rast je uslijedio tek od 2014. godine, ali razine tog koeficijenta su vrlo niske. Uzimajući u obzir da se ovdje razmatraju prosječni pokazatelji za sektor nefinancijskih poduzeća, razlike od djelatnosti do djelatnosti, kao i između poduzeća u okviru iste djelatnosti, bitno se razlikuju. Stoga u interpretaciji tog pokazatelja na razini cijelog sektora treba se uglavnom zadržati na dinamici promjena. U daljnjoj analizi u obzir treba uzeti koliko su na sastavnice tog pokazatelja utjecale promjene u strukturi poduzeća, tj. ulazak i izlazak s tržišta, odnosno promjene obuhvata poslovnih subjekata u bilanci na razini sektora nefinancijskih poduzeća. Nadalje, treba voditi računa i o tome da, uz koeficijent likvidnosti, na razini pojedinačnog poduzeća treba imati uvid i u njegovu strukturu kratkotrajne imovine i koefici- 
Grafički prikaz 4.

\section{LIKVIDNOST, ZADUŽENOST I SOLVENTNOST PODUZEĆA I KVALITETA PLASMANA BANAKA U HRVATSKOJ U RAZDOBLJU OD 2001. DO 2016. GODINE}

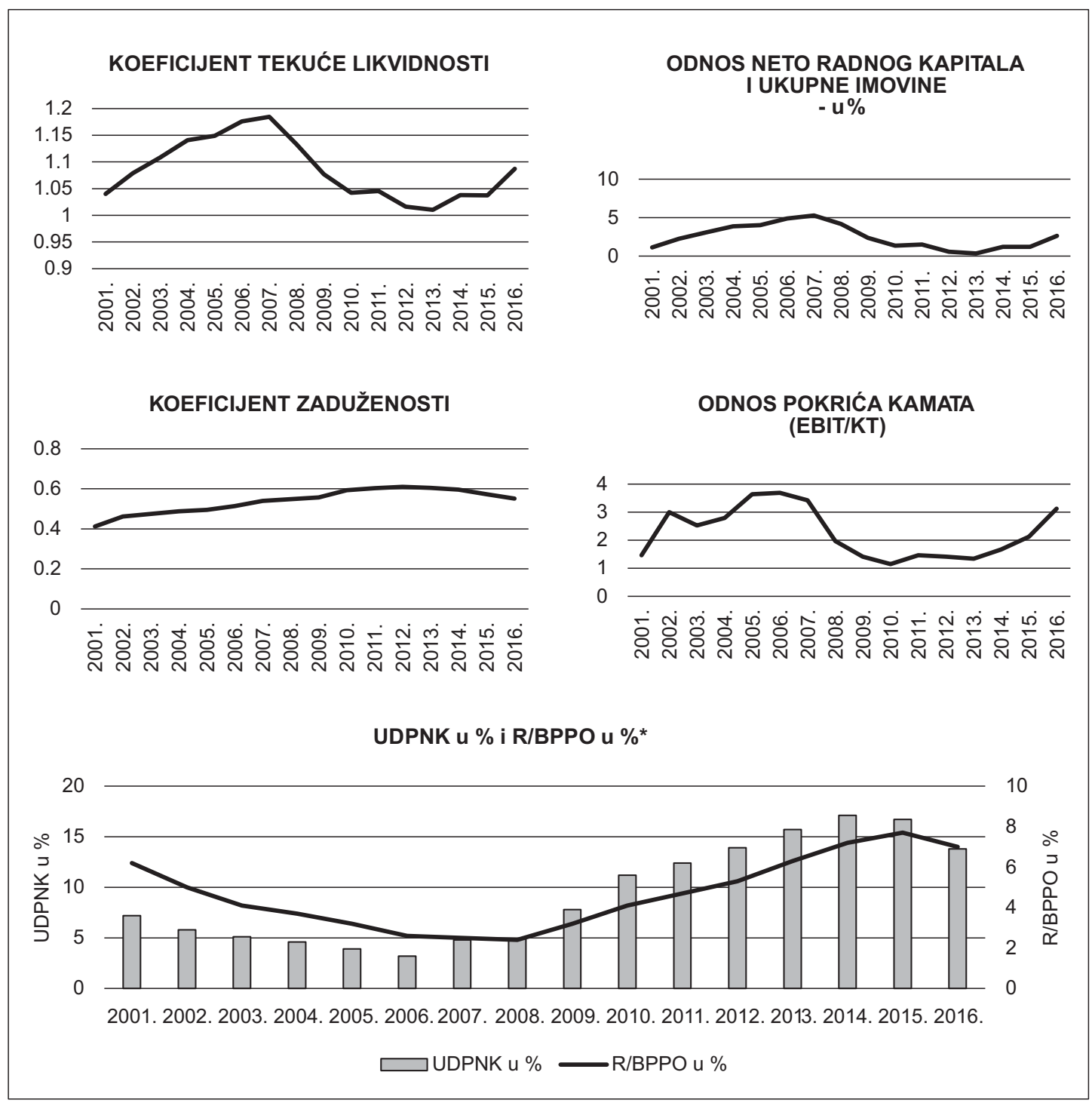

*UDPNK = udjel djelomično nadoknadivih i potpuno nenadoknadivih kredita banaka u \%; R/BPPO $=$ omjer rezervacija i bruto plasmana i potencijalnih obveza $(\mathrm{A}, \mathrm{B}, \mathrm{C}, \mathrm{D}, \mathrm{E}) \mathrm{u} \%$.

Izvor: Na temelju izračuna autora iz podataka preuzetih iz godišnjih publikacija: Financijska agencija, Analiza financijskih rezultata poduzetnika Republike Hrvatske i Hrvatska narodna banka: Godišnje izvješće i Bilten o bankama. 
jente obrtaja njezinih nenovčanih komponenti, kako bi se spoznao stvarni stupanj likvidnosti. Naravno, to sve samo na temelju podataka sintetiziranih na razini cijelog sektora nije moguće procijeniti. Potrebni su detaljniji uvidi kako bi ovakvi pokazatelji, uz makroekonomske indikatore, bili cjelovita analitička podloga za korektivne mjere u reguliranju usklađenog funkcioniranja razmatranih sektora.

Sastavnice pokazatelja likvidnosti, na razini sektora nefinancijskih poduzeća, kretale su se različito. Kratkotrajna imovina je na najvišoj razini bila 2008. godine, a nakon te godine stagnira ili se smanjuje. Kratkoročne obveze su se povećavale sve do 2011. godine kada je ostvarena njihova najviša razina, a nakon toga su se uglavnom smanjivale. Razlika između kratkotrajne imovine i kratkoročnih obveza, tj. neto radni kapital poduzeća se od 2001. do 2007. iz godine u godinu povećavao. Nakon toga (izuzetak je samo 2011. godina) njegova razina se smanjuje. Najniža razina neto radnog kapitala bila ju u 2013. godini. Blagi oporavak je uslijedio tek od 2014. godine.

Udjel neto radnog kapitala u ukupnoj imovini se od razine $1,11 \%$ povećao na 5,28\% u 2007. godini. Od tada se taj udjel smanjuje (s izuzetkom 2011. godine) do najniže razine od $0,34 \%$ u 2013. godini. Blago poboljšanje uslijedilo je tek od 2014. godine. Pokazatelj udjela neto radnog kapitala u ukupnoj imovini odražava razmjere problema opće nelikvidnosti u hrvatskom gospodarstvu u razdoblju recesije. S obzirom na njegovo znatno smanjenje već u 2008. godini, mogao je poslužiti nositeljima ekonomske politike da provedu daljnju dubinsku analizu i pravovremeno prepoznaju dimenzije trenda pogoršanja koje će nužno uslijediti ako se ne poduzmu koordinirane mjere financijske discipline i antirecesijskog djelovanja.

Dugoročne obveze poduzeća su se povećavale u cijelom promatranom razdoblju s izuzetkom u 2012. i 2013. kada je ostvareno blago smanjenje te stagnacija. Kratkoročne obveze su se povećavale do 2011. godine. Do tada su se povećavale $\mathrm{i}$ ukupne obveze poduzeća. Ta su se kretanja odrazila na koeficijent zaduženosti poduzeća koji se u promatranom razdoblju kontinuirano povećavao od 2001. pa do 2012. godine, kada je dosegnuo razinu od 0,61. Nakon toga, nastupilo je razdoblje razduživanja poduzeća, tj. tzv. minimiziranja duga (termin koji se uz koncept recesije na bilanci koristi u Koo, 2009) i produljena recesija hrvatske ekonomije. Nakon toga procesa u 2016. godini koeficijent zaduženosti bio je na razini 0,55 (za usporedbu zaduženosti poduzeća u Hrvatskoj i Europskoj uniji vidjeti u HNB, 2016a i 2016b).

Omjer dobiti prije kamata i poreza (EBIT-a) i kamatnih troškova, tj. pokazatelj pokrića kamata nefinancijskih poduzeća, znatno se smanjio već na početku recesijskog razdoblja. To je trebao biti dodatni signal nastupanja razdoblja duboke nesolventnosti za znatan dio poduzeća hrvatskog gospodarstva.

U opisanim uvjetima znatno pogoršanih pokazatelja likvidnosti, zaduženosti i solventnosti, u sektoru nefinancijskih poduzeća, udjel djelomično nadoknadivih i potpuno nenadoknadivih kredita banaka se od 2008. do 2014. povećavao iz godine u godinu. Povezano s tim povećavao se i omjer rezervacija i bruto plasmana i poten- 
cijalnih obveza. Na taj se način pokazuje kako s određenim vremenskim pomakom slabe performanse hrvatskog gospodarstva utječu na banke. Nadalje, ugrađujući kompenzaciju za povećane rizike plasiranja sredstava poduzećima u cijenu kredita, uz sve ostale negativne utjecaje, začarani krug funkcioniranja realne i financijske sfere hrvatske ekonomije i dalje ostaje izvan poželjnih ekonomskih ishoda.

\subsection{Usporedba profitabilnosti poduzeća i banaka}

Za procjenu ostvarivanja profitabilnosti banaka u uvjetima kontrakcije gospodarskih aktivnosti i pogoršanja financijskih performansi poduzeća razmatraju se pokazatelji povrata na kapital i povrata na imovinu i sastavnice tih pokazatelja. U vezi s tim na grafičkom prikazu 5. vidljivo je ostvarivanje povrata na kapital i povrata na imovinu za poduzeća i banke u Hrvatskoj u razdoblju od 2001. do 2016. godine.

Grafički prikaz 5.

\section{PROFITABILNOST PODUZEĆA I BANAKA U HRVATSKOJ U RAZDOBLJU OD 2001. DO 2016. GODINE}

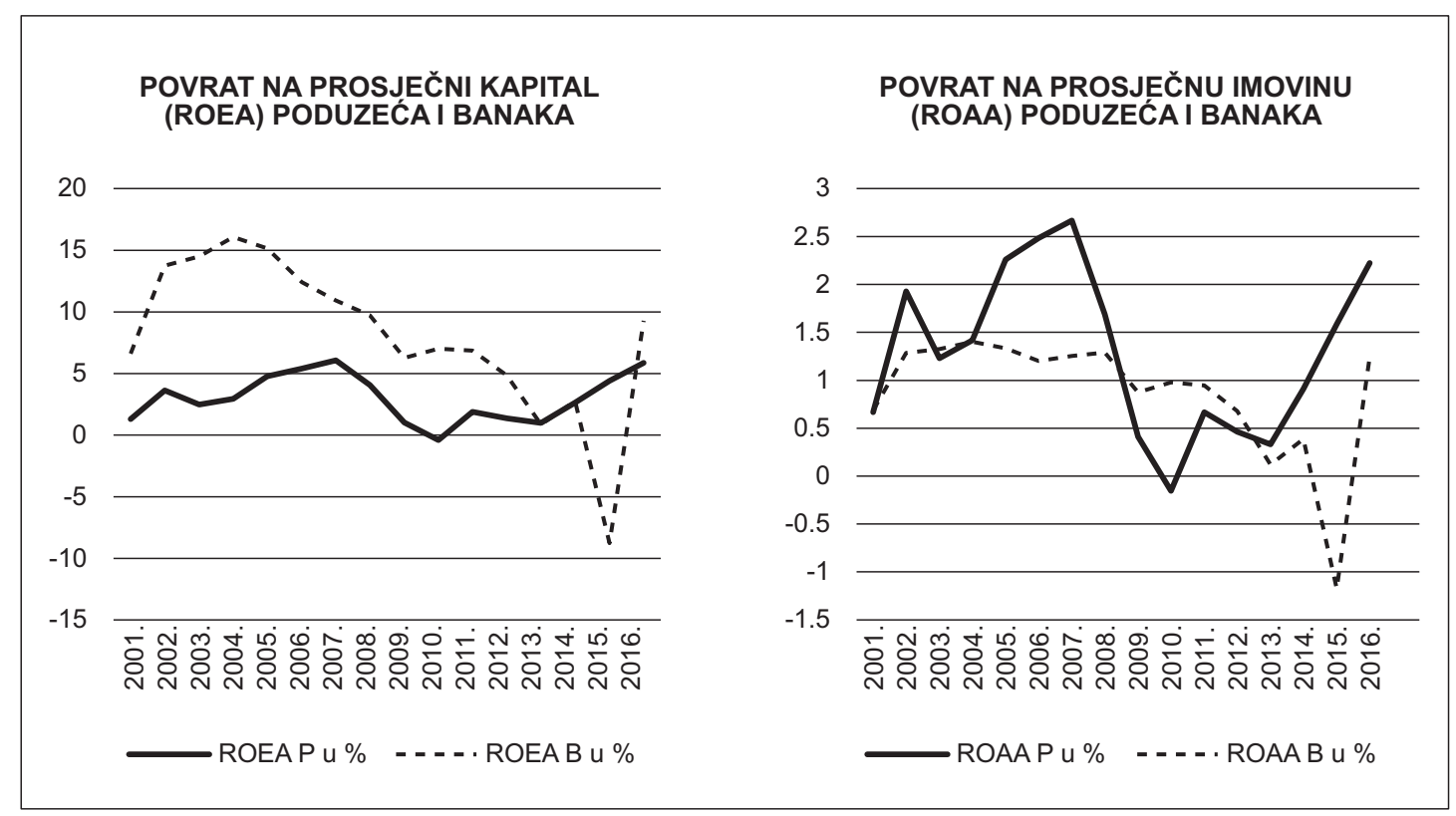

Izvor: Na temelju izračuna autora iz podataka preuzetih iz godišnjih publikacija: Financijska agencija, Analiza financijskih rezultata poduzetnika Republike Hrvatske i Hrvatska narodna banka: Godišnje izvješće i Bilten o bankama. 
Brzi rast kredita, uz kamatne stope i kamatni spread iznad stopa i spreada u eurozoni ( o tome u Krnić 2014, 2015) omogućavao je uspješno poslovanje bankovnog sektora u Hrvatskoj sve do početka globalne financijske krize. Međutim, kontrakcijom gospodarskih aktivnosti i smanjivanjem prihoda poduzeća, te povezano s tim i novčanih primitaka, sposobnost plaćanja obveza po preuzetim kreditima od 2009. godine bitno je smanjena. To je uzrokovalo porast nenaplativih potraživanja banaka i pogoršanje uspješnosti njihova poslovanja. Kao posljedica toga, povrat na kapital i povrat na imovinu su smanjeni.

Grafički prikaz 6.

\section{STAVKE U IZRAČUNU PROFITABILNOSTI PODUZEĆA I BANAKA U HRVATSKOJ U RAZDOBLJU OD 2001. DO 2016. GODINE}

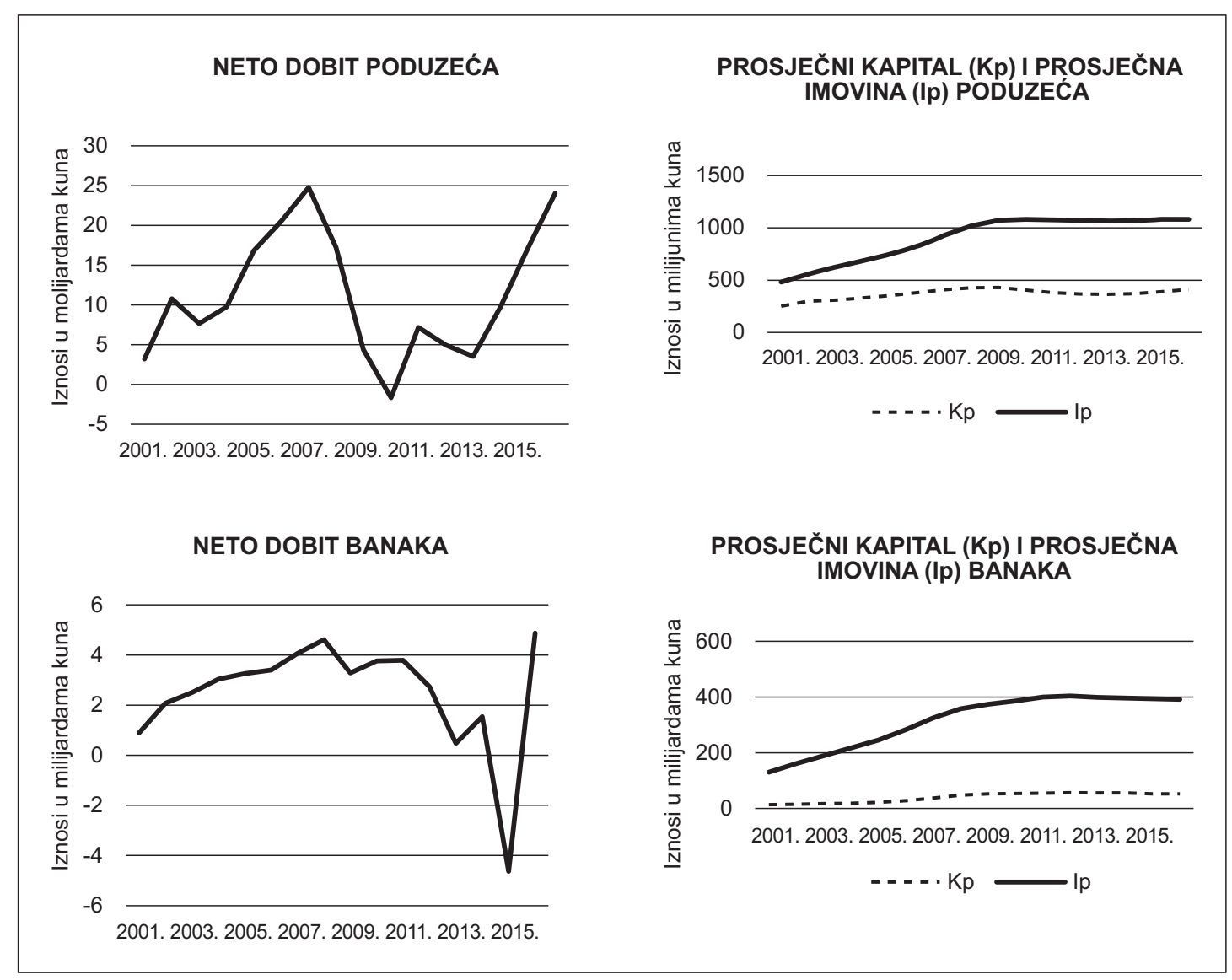

Izvor: Na temelju izračuna autora iz podataka preuzetih iz godišnjih publikacija: Financijska agencija, Analiza financijskih rezultata poduzetnika Republike Hrvatske i Hrvatska narodna banka: Godišnje izvješće i Bilten o bankama. 
$\mathrm{Na}$ grafičkom prikazu 6. prikazane su stavke koje predstavljaju sastavnice povrata na kapital i povrata na imovinu poduzeća i banaka u Hrvatskoj. Navedeni prikazi omogućuju uvid u neusklađenost razmatranih sektorskih profitabilnosti koji proizlaze iz utvrđenih disproporcija u kretanju njihovih ukupnih prihoda i ukupnih troškova u pojedinim razdobljima. Time se također potvrđuju s određenim vremenskim pomakom i sektorske međuovisnosti u njihovu funkcioniranju. Kontrakcija gospodarskih aktivnosti i općenito pogoršanje u financijskim performansama poduzeća s određenim vremenskim pomakom utječe i na pogoršanje financijskog položaja i uspješnosti banaka. Povećanje nenaplativih kredita od poduzeća povećava ispravke vrijednosti i rashode banaka, a povećana premija rizika neplaćanja povećava kamatne troškove poduzeća i pogoršava njihov financijski položaj i uspješnost poslovanja.

U takvim interakcijama, bez provođenja osmišljenih promjena u korporacijskom upravljanju, regulaciji i ekonomskoj politici, ne stvaraju se uvjeti za usklađeno funkcioniranje realne i financijske sfere hrvatske ekonomije i za njezine optimalne ekonomske ishode.

\subsection{Posebnosti i ograničenja u istraživanju i daljnja istraživanja}

U ovom se radu, unatoč ograničenom obuhvatu financijskih pokazatelja i uz izostavljanje drugih bitnih aspekata analize, potvrđuju, ali i u znatnoj mjeri proširuju nalazi ranijih istraživanja. Pri tome treba uzeti u obzir da se većina ranijih istraživanja odnosi na odvojeno razmatranje sektora poduzeća i bankovnog sektora te da se ovim radom inaugurira pristup usporedne analize. Nadalje, uz ostvarenje proklamiranog cilja istraživanja i pribavljanja odgovora na postavljena istraživačka pitanja, u radu je pokazana korisnost primjene financijskih pokazatelja sektora nefinancijskih poduzeća i bankovnog sektora kao dopune indikatora makroekonomskih kretanja. U ranijim istraživanjima taj aspekt najčešće nije bio zastupljen.

Imajući u vidu da su odabrane stavke iz financijskih izvještaja i financijski pokazatelji iskazani na razini sektora nefinancijskih poduzeća, za interpretaciju rezultata bile bi potrebne i analitike radi razlikovanja ostvarenja pojedinih gospodarskih djelatnosti. Stoga bi nalaze istraživanja trebalo interpretirati i u povezanosti s istraživanjima koja se odnose na pojedine djelatnosti, kao i s nalazima iz postupaka detaljnijeg raščlanjivanja utjecaja na promjene.

U radu se ukazuje i na mogućnost budućih istraživanja u kojima bi se identificirane financijske performanse poduzeća i banaka razmatrale u kontekstu poduzetih mjera ekonomske politike i u okviru nje - monetarne politike. Takav obuhvat istraživanja mogao bi biti proširen i u kontekstu međunarodni usporedbi. 


\section{Zaključak}

Cilj je ovog istraživanja bio proširiti dosadašnje spoznaje o međuovisnosti funkcioniranja financijskog i realnog sektora u hrvatskoj ekonomiji. U tu je svrhu istražena dinamika promjena financijskog položaja i financijskih rezultata poduzeća i banaka, kao njihovih ključnih sastavnica. Provedeno istraživanje omogućilo je dobivanje odgovora na postavljena istraživačka pitanja. Utvrđene su razlike u kretanju dijela kategorija uspješnosti i financijskog položaja poduzeća i banaka, osobito u recesijskom razdoblju. U istraživanju odnosa odabranih stavki za poduzeća i banke u okviru procedure linearne regresije utvrđeni su različiti stupnjevi njihove povezanosti. Pokazano je da se kvaliteta bankovnih plasmana, kao i s određenim pomakom profitabilnost banaka, smanjuju u uvjetima pogoršanja financijskih performansi poduzeća, osobito pokazatelja njihove likvidnosti i solventnosti.

Nalazi provedenog istraživanja potvrđuju teorijske osnove o međuovisnosti kretanja financijske i realne sfere ekonomije. Mogu pridonijeti boljem razumijevanju interakcija na tom području i ukazuju na potrebu da se, uz makroekonomske indikatore, za pravovremeno prepoznavanje i otklanjanje međusektorskih nesrazmjera, trebaju više koristiti komparativna sektorska analiza pokazatelja izračunatih iz stavki temeljnih financijskih izvještaja poduzeća i banaka.

Povezivanje identificiranih financijskih performansi poduzeća i banaka s poduzetim mjerama ekonomske politike i u okviru nje - monetarne politike, mogao bi biti predmet budućih istraživanja. To bi pridonijelo dobivanju ključnih pouka za regulaciju i ekonomsku politiku, na temelju usporednog razmatranja financijskih performansi poduzeća i banaka, indikatora makroekonomskih kretanja i poduzetih mjera ekonomske politike.

\section{Literatura:}

Altman, E. I. (1968). Financial ratios, discriminant analysis and the prediction of corporate bankruptcy. Journal of Finance, 23 (4), 589-609. doi:10.2307/2978933.

Bajo, A. i Primorac, M. (2016). Financial performance of major public enterprises in Croatia from 2006 to 2014. Economia pubblica 3, 117-148. doi:10.3280/ EP2016-003005.

Belak, V. i Aljinović Barać, Ž. (2008). Tajne tržišta kapitala: BEX indeks, analiza financijskih izvještaja, pokazatelji efikasnosti ulaganja i modeli odlučivanja. Zagreb: Belak Excellens. 
B. KRNIĆ i I. BELJAN: Dinamika promjena financijskog položaja i financijskih rezultata poduzeća i banaka...

EKONOMSKI PREGLED, 70 (6) 869-894 (2019)

Beljan, I. (2017). Usporedna analiza uspješnosti i ekonomskog stanja poduzeća $i$ banaka u Hrvatskoj. Specijalistički diplomski stručni rad (mentor: B. Krnić). Zagreb: Veleučilište VERN'.

Belak V. (2014.), Analiza poslovne uspješnosti - 130 ključnih pokazatelja performanse i mjerila za kontroling, Zagreb: RRIF Plus.

Berger, A. N. i Humphrey, D. B. (1997). Efficiency of financial institutions: international survey and directions for future research. Finance and Economics Discussion Series 1997-11, Board of Governors of the Federal Reserve System (U.S.). Dostupno na: https://www.federalreserve.gov/pubs/feds/1997/199711/1 99711pap.pdf

Berger, A. N. i Mester,L. J. (1997). Inside the Black Box: What Explains Differences with Efficiency of Financial Institutions? Journal of Banking and Finance 21, 895-947. Dostupno na: https://www.sciencedirect.com/science/article/pii/ S0378426697000101

Coad, Alex (2009). The growth of firms: a survey of theories and empirical evidence. New perspectives on the modern corporation series . Edward Elgar Publishing. ISBN 978184844327.

Demirguc-Kunt, A. i Detragiache, E (1998). Determinants of Banking Crises in Developing and Developed Countries. Staff Papers (International Monetary Fund), 45(1), 81-109. doi:10.2307/3867330.

Demirguc-Kunt, A., Detragiache, E. i Gupta, P. (2006). Inside the crisis: An empirical analysis of banking systems in distress. Journal of International Money and Finance, 25 (5), 702-718. Dostupno na: https://www.sciencedirect.com/ journal/journal-of-international-money-and-finance/vol/25/issue/5

Demirgüç-Kunt, A. i Levine, R. (2008). Finance, financial sector policies, and long-run growth. Policy Research Working Paper Series, 4469. Dostupno na: http://documents.worldbank.org/curated/en/6356914 68158710957/pdf/ wps4469.pdf

Dumičić, M. (2015). Financijski pokazatelji stabilnosti - primjer Hrvatske. HNB. Istraživanja, 46. Dostupno na: https://www.hnb. hr/documents/20182/282890/i-046.pdf/05284060-732c-4e27-a935b14ce91e1f09

Financijska agencija, Analiza financijskih rezultata poduzetnika Republike Hrvatske, razne godine.

Fries, S. i Taci, A. (2004). Cost efficiency of banks in transition: Evidence from 289 banks in 15 post-communist countries. EBRD. Working paper, 86. Dostupno na: http://www.ebrd.com/downloads/ research/economics /workingpapers/ wp0086.pdf 
Gadanecz, B. i Jayaram, K. (2009). Measures of financial stability - a review. BIS, Proceedings of the IFC Conference on ,Measuring financial innovation and its impact"،, 51 (str. 365 - 380). Dostupno na http://www.bis.org/ifc/publ/ ifcb31ab.pdf

Gertler, M. (1988). Financial Structure and Aggregate Economic Activity: An Overview“, Journal of Money, Credit and Banking, 20(3), 559-588. Dostupno na: http://www.nviegi.net/teaching/master/gertler .pdf

HNB, Bilten. https://www.hnb.hr/analize-i-publikacije/redovne-publikacije/bilten

HNB, Financijska stabilnost.https://www.hnb.hr/analize-i-publikacije/redovnepublikacije /financijska-stabilnost

HNB, Godišnje izvješće. https://www.hnb.hr/analize-i-publikacije/redovne-publikacije/ godisnje-izvjesce

HNB (2016a). Financijska stabilnost, 16. Dostupno na: https://www.hnb.hr/-/financijska-stabilnost-16

HNB (2016b). Financijska stabilnost, 17. Dostupno na: https://www.hnb.hr/-/financijska-stabilnost-17

HNB (2017). Financijska stabilnost, 18. Dostupno na: https://www.hnb.hr/-/financijska-stabilnost-18

HNB (2018). Bilten, 242. Dostupno na: https://www.hnb.hr/analize-i-publikacije/ redovne-publikacije/bilten

Horrigan, J. (1968). A Short History of Financial Ratio Analysis. The Accounting Review, 43(2), 284-294. Dostupno na: http://www.jstor.org/stable/243765

Ježovita, A. i Žager, L. (2014). Ocjena zaduženosti poduzeća pokazateljima profitabilnosti. Zbornik Ekonomskog fakulteta u Zagrebu, 12(1), 1-22. Dostupno na: https://hrcak.srce.hr/124753. ISSN 1845-495X

Ježovita, A. (2015). Ocjena sigurnosti poslovanja poduzeća realnog sektora u Republici Hrvatskoj. Zbornik Ekonomskog fakulteta u Zagrebu, 13(1), 75-91. Dostupno na: https://hrcak.srce.hr/141097. ISSN 1845-495X

Kester, W. (1986). Capital and Ownership Structure: A Comparison of United States and Japanese Manufacturing Corporations. Financial Management, 15(1), 5-16. Dostupno na: http:/eds.b.ebscohost.com / eds/pdfviewer/pdfviewer?vid=8\&sid=cbcf03df-45dc-4c83-836fdb8b3ebc1799\%40sessionmgr102

Koo, R. C. (2009). The Holy Grail of Macroeconomics: Lessons from Japan's Great Recession. Singapore: John Wiley \& Sons (Asia) Pte. Ltd.

Krnić, B. i Radošević, D. (2014). Makroekonomske neravnoteže u hrvatskoj ekonomiji: dualitet između financijskog i realnog sektora. Ekonomski pregled, 65(1), 3-34. Dostupno na: https://hrcak.srce.hr/117903 
B. KRNIĆ i I. BELJAN: Dinamika promjena financijskog položaja i financijskih rezultata poduzeća i banaka...

EKONOMSKI PREGLED, 70 (6) 869-894 (2019)

Krnić, B. (2014). Determinants of lending interest rates granted to companies in Croatia. Journal of Accounting and Management, 4(2), 1-20. Dostupno na: https://hrcak.srce.hr/143422

Krnić, B. (2015). Interest rates on corporate loans in Croatia as an indicator of imbalance between the financial and the real sector of national economy. International Journal - Vallis Aurea, 1(2), 41-55. doi:10.2507.IJVA.1.2.5.1.

Krnić, B. (2016). Risks to financial stability of Croatia in international comparison. Journal of Accounting and Management, 6(2), 1-24. Dostupno na: https://hrcak.srce.hr/177191

Krnić, B. (2017.). Financijske performanse poduzeća i banaka u Hrvatskoj - identifikacija nesrazmjera. U: Đ. Jurić (ur.), Zbornik radova 18. međunarodne znanstvene $i$ stručne konferencije „Računovodstvo i financije - RiM“, Zagreb, Hrvatski računovođa i RRIF Visoka škola za financijski menadžment (str. 101-126). Dostupno na: http://www.hrvatski-racunovodja.hr/pub/2017/rim2017-zbornik-znanstvenih-radova.pdf

Kundid, A., Škrabić, B. i Ercegovac, R. (2011). Determinants of bank profitability in Croatia. Croatian Operational Research Review, 2(1), 168-182. Dostupno na: https://hrcak.srce.hr/96661

Levine, R. (1997). Financial Development and Economic Growth: Views and Agenda. Journal of Economic Literature, 35(2), 688-726. Dostupno na: https://www.researchgate.net/profile/Ross_Levine/publication/ 4722931_ Financial_Development_And_Economic_Growth_Views_And_Agenda/ links/0046352065300861d3000000.pdf

Levine, R. (2004). Finance and Growth: Theory and Evidence. NBER Working Paper, 10766. Dostupno na: http://www.nber.org/papers/w10766

Minsky, H. P. (1992). The Financial Instability Hypothesis, The Jerome Levy Economics Institute Working Paper, 74. Dostupno na: http://www.levyinstitute.org/pubs/wp74.pdf

Minsky, H. P. (2008). Stabilizing an Unstable Economy, New York: McGraw Hill.

Pagano, M. (1993). Financial Markets and Growth: An Overview, European Economic Review, 37(2-3), 613-622. Dostupno na: http://www.csef.it/pagano/ eer-1993.pdf

Pejić Bach, M., Posedel, P. i Stojanović, A. (2009). Determinante profitabilnosti banaka u Hrvatskoj. Zbornik Ekonomskog fakulteta u Zagrebu, 7(1), 81-92. Dostupno na https://hrcak.srce.hr/4054.

Seiford, L., M i Zhu, J (1999). Profitability and Marketability of the Top 55 U.S. Commercial Banks Management Science, 45 (9), 1270-1288. Dostupno na: https://pdfs.semanticscholar.org/575f/48bcb9fb555 715d0f9b15e7fc42a456c64.pdf 
Stevens, D. (1973). Financial Characteristics of Merged Firms: A Multivariate Analysis. The Journal of Financial and Quantitative Analysis, 8(2), 149-158. doi:10.2307/2330007.

Šverko, I., Pavlović, A. i Vukas, J. (2012). Analiza poslovanja malih banaka u Republici Hrvatskoj . Privredna kretanja i ekonomska politika, 22(133), 2746. Dostupno na: https://hrcak.srce.hr/97598

Webb R. (2010). Levels of efficiency in UK retail banks: a DEA window analysis, International Journal of the Economics of Business, 10:3, 305322, doi: 10.1080/1357151032000126256.

Žager, L. (2001). Analiza financijskih izvještaja - poduzeće, banka. U: B. Krnić i V. Miloslavić (ur.). Zagreb: TEB-ov bankovni priručnik - seminarske. ISBN 953-6290-18-9. (str. 147 - 162).

Žager, K., Mamić Sačer, I., Sever Mališ, S., Ježovita, A. i Žager. L. (2017). Analiza financijskih izvještaja - načela, postupci, slučajevi. Treće izmijenjeno i dopunjeno izdanje. Zagreb: Hrvatska zajednica računovodstvenih i financijskih djelatnika.

\section{DYNAMICS OF CHANGES IN THE FINANCIAL POSITION AND FINANCIAL RESULTS OF COMPANIES AND BANKS IN CROATIA}

\section{Summary}

The purpose of this research is to expand the present understanding of the interdependence between the functioning of the financial sector and the real sector in the Croatian economy. To that effect, the dynamics of changes in the financial position and the financial performance of their key components, i.e. companies and banks, are explored. Compared with previous research, the aspects and the time horizon of the analysis are broadened, the recession period of the Croatian economy is considered more closely and the scope of financial indicators is redefined. Comparisons are made on the basis of the growth ratio index, as well as the relationship between the basic components of the linear regression model and the selected sectoral financial indicators. Differences were found in the movement of a part of the performance and financial position categories of enterprises and banks during the period of recession and it was shown that the quality of placement and, to a certain degree, the banks' profitability have been deteriorating in conditions of deterioration of liquidity and solvency indicators of the company. The findings of this research may contribute to a better understanding of the interdependence of the financial and real sector of the economy and the recognition of the need for the greater use of comparative sectoral analysis of aggregated data and indicators from financial statements, along with macroeconomic indicators, for a timely recognition and elimination of cross-sectoral disparities.

Keywords: financial position, business performance, companies, banks 